\title{
The gamma radiation shielding effectiveness of textured steel yarn based fabrics
}

\section{REZUMAT - ABSTRACT}

\section{Eficiența ecranării radiațiilor gamma a țesăturilor cu conținut de fire din oțel texturat}

Vestele de protecție pe bază de plumb care au eficiență împotriva radiațiilor electromagnetice sunt utilizate, în general, pentru protecția personală a medicilor și a pacienților împotriva radiațiilor X (gamma) în timpul operațiilor din domeniul medical; cu toate acestea, plumbul are dezavantaje ecologice, având toxicitate ridicată. Scopul acestui studiu a fost de a realiza un material de protecție împotriva radiațiilor pe bază de materiale textile ecologice și flexibile. În această lucrare au fost utilizate tesături 2/2 diagonal, 3/1 diagonal, Herringbone, Whipcord, care sunt derivate din legătura diagonal, țesături Barathea și Crêpe, derivate din legătura satin, țesături cu fire de oțel texturate, care au tușeu moale și sunt flexibile, pentru care s-a investigat eficiența ecranării radiațiilor gamma, care nu a fost studiată în referințe.

Efectele caracteristicilor structurale ale țesăturilor, cum ar fi tipul de legătură, densitatea firului de bătătură, grosimea țesăturii și porozitatea, au fost analizate grafic și statistic. Se observă că, având cele mai mari grosimi și cele mai scăzute porozități, țesăturile Barathea și Crêpe au avut performanțe mai bune de ecranare a radiațiilor gamma decât celelalte tipuri de țesături. Probele F1 și E1, țesute cu legături Barathea și Crêpe, au cea mai mare eficacitate de ecranare a radiației gamma, datorită celei mai mari de grosimi a țesăturii și a celei mai scăzute porozități. În plus, creșterea densității firelor de oțel texturat a îmbunătățit eficacitatea ecranării radiației gamma a țesăturilor.

Cuvinte-cheie: legătură diagonal, legătură derivată, țesături, radiație gamma, eficiența ecranării radiațiilor gamma, fir de oțel texturat

\section{The gamma radiation shielding effectiveness of textured steel yarn based fabrics}

Lead aprons that are lead-shielding products are generally used for personal protection of physicians and patients from $X$-ray (gamma) radiation during medical operations; lead has environmental disadvantages, with high toxicity, though. Therefore, the aim of this research was to produce an environmentally friendly and flexible textile-based radiation shielding material. In this work, 2/2 twill, 3/1 twill, Herringbone, Whipcord, which are twill derivatives, Barathea and Crêpe woven fabrics, which are sateen derivatives, woven with textured steel yarns, which have soft feeling and flexibility, and gamma radiation shielding effectiveness of these fabrics were investigated and were not studied in the references.

The effects of fabric structural characteristics such as weave, conductive weft yarn density, fabric thickness and porosity on these properties were analysed graphically and statistically. It is observed that with the biggest thicknesses and lowest porosities, Barathea and Crêpe woven fabrics performed better gamma radiation shielding performance than other woven fabrics. The samples F1 and E1, woven with Barathea and Crêpe weave, have the highest gamma radiation shielding effectiveness, thanks to the highest fabric thicknesses and lowest porosities. In addition, the increases of textured steel yarn density improved the gamma radiation shielding effectiveness of woven fabrics.

Keywords: twill weave, derivative weave, woven fabrics, gamma radiation, gamma radiation shielding effectiveness, textured steel yarn

\section{INTRODUCTION}

Apart from three basic weaves namely plain, twill and sateen weaves, there are derivative of these weaves. The idea behind developing these weaves is to obtain physical and aesthetic characteristics in the fabric somewhat different than those obtained with the basic weaves. In derivative weaves properties intermediary between these main groups are obtained. This is achieved by rearranging the basic weave structures by the application of certain methods to give the desired result [1].

As a generalized notion, the radiation is propagation of electromagnetic or particle energy which are two portions of radiation concept. However, the radiation is the general name of different characteristic energies. Radiations kinds realize the radiation spectrum.
Many of radiation kinds are known by the people such as visible light, heat, radio waves, ultra violet waves (UV) and micro waves but not know they are radiation. All radiation types of electromagnetic energy are made by the same thing which is just electric and magnetic field coupling but different frequencies. Visible region is the frontier in the large electromagnetic radiation spectrum. As energy value, under the light all kinds of radiations cannot damage the matter although make a specific interaction. After light energy (figure 1) the radiation has a name: ionizing radiation and nuclear radiation. UV region starts to damage the matter by separating the electrons.

While the frequency increases the energy of the radiation decreases. Visible region has several $\mathrm{eV}$ (electronvolt, $1 \mathrm{eV}=1.6 \times \mathrm{E}^{-19}$ Joule) unit energy but 
UV region has several keV (kilo eV). $13.6 \mathrm{eV}$ energy is needed to separate an electron from hydrogen atom but visible and other regions under UV have not enough such energy. $X$ ray regions have energies several ten keV to several MeV. Secondly, after the electromagnetic radiation, there is particle radiation that has completely effect of ionizing. These particles come from atomic nuclei of radioactive materials, outer space and scientific facilities. Alpha, beta and neutrons are commonly used and known in many of particle type. Particle radiation can be easily shielded and there cannot be faced

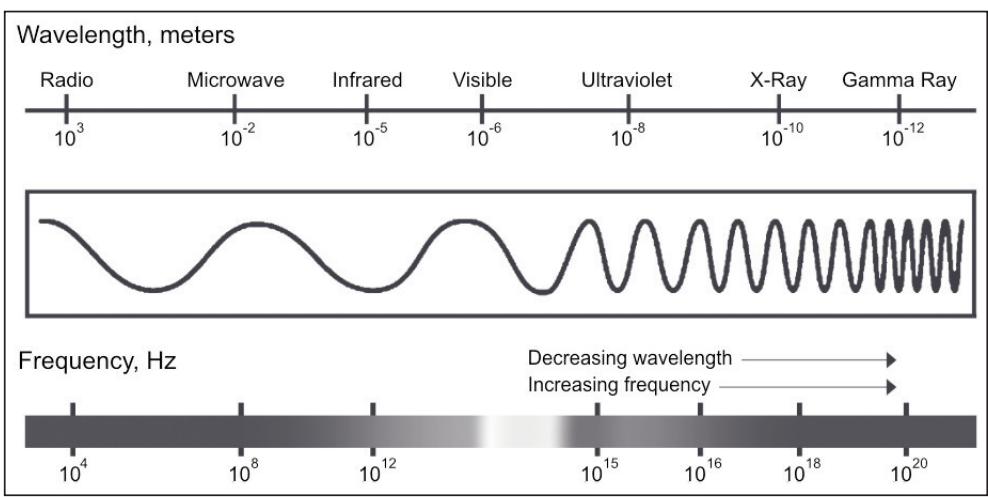
in people life. On the other hand, electromagneticionizing radiation cannot be easily stopped. So it is important to care ionizing radiation for alive organism because ionizing radiation definitely damages the DNA. The DNA damages are commonly repaired by the organism but always there are permanent DNA damage risks. Sometime the risk turns into reality of cancer or genetically mutation. In practical life, we live in lonizing Radiation Sea additionally other nonionizing radiations. Natural earth materials and the sun are main radiation source for us. Also, humans can face the ionizing radiation artificially by medical applications which include diagnostic and therapy treatments.

Humans try to avoid all the radiation types as degree of their information about radiation concept. Although protection of particle radiation does not need remarkable effort, electromagnetic radiation, also particularly the ionizing region of the electromagnetic spectrum has wide research and job area in radiation protection. Especially, medical physics area almost consists of ionizing or nuclear radiation applications. The people that are except radiation workers are named the public in ionizing radiation application. Radiation workers have more widen tolerance protocols than public because of their controlled conditions. However, the conditions are not controlled in radiation protection in the practical life of the public. Commercially, there are many products which put forwarding a protection for radiation shielding. Many of them are useless and out of scientific realities. Despite these, it is needed to protect the people from ionizing radiation. Annual radiation dose that comes from cosmic and terrestrial radiation is $2.4 \mathrm{mSv}$ meanly [3-5] and this value is higher than a single lung Rontgen exposure [6]. Also, radiation workers need continuous protection shielding instead of heavy lead during daily medical jobs out of specific radiation treatments.

User friendly and light wearing fabrics or materials have been always important the subject of radiation protection in scale from high school's projects to specialized scientific researches. Therefore researchers applied chemical treatments to enhance the gamma radiation shielding effectiveness of fabrics:

Fig. 1. Electromagnetic radiation spectrum [2]

Maghrabi et al. coated $100 \%$ polyester and nylon plain woven fabrics with bismuth oxide [7]. They found that coated polyester fabrics with over $50 \%$ $\mathrm{Bi}_{2} \mathrm{O}_{3}$ showed enhanced shielding ability for transmitted X-rays. Aral, Nergis and Candan coated the cotton fabrics with silicone rubber that contains tungsten, bismuth or barium sulphate powders in equal weight fractions [8]. The results showed that, at $60 \%$ weight ratio, $1.55 \mathrm{~mm}$ bismuth embedded coating could attenuate $90 \%$ of X-ray photons at the $100 \mathrm{kV}$ level, while the required thickness of a tungsten embedded coating was $1.73 \mathrm{~mm}$ for the same protection level. Qu et al. fabricated a series of X-ray radiation-resistant fibres via a primarily industrialized wet-spinning trail, and knitted the resultant fibres into fabrics by knitting loom [9]. The X-ray attenuation ratio of the sample tended to increase with increasing barium sulphate content and finally reached a dose of a $0.1 \mathrm{~mm}$ thick lead equivalent.

Electromagnetic-ionizing radiation is absorbed in different percentages by different element media. While atomic number of element increases, absorption fraction increases so the lead has the heaviest number in periodic table as friendly usage. Material technology or composition cannot affect the absorption amount, just atomic number or effective atomic number (effective atomic number is defined for mixtures or compounds similar element numbers in nuclear science) of material elements. In consideration of fabric production techniques, technologies and science, radiation-mass interactions are not relevant with them. Mechanism of radiation interactions is directly dependent on mass atomic properties and initial radiation energy. So the shielding made by lead is popular and indispensable still despite improved technology of humankind because the lead atoms have heavy and wide nuclei independently from macro features of materials. This cannot be ignored to develop radiation shielding materials. The way is inserting material with heavy atom into the expected fabric for significant radioprotection.

The studies in literature focused on chemical treatment of plain woven fabrics. However gamma radiation shielding effectiveness of fabrics woven with textured steel yarns has not been investigated. If a fabric is required to be radiation-shielded, firstly it should 
include bigger atomic number material in its pattern. Common fabrics were manufactured with organic or synthetic materials which do not contain bigger atom than themselves. Metals are most suitable matters for radiation protection so in this study stainless steel contributed fabric was investigated. Steel is consisting of mostly iron and rarely carbon. Carbon fraction determines the type of the steel. Iron has 26 atomic number. This is almost bigger than common fabric material atoms. There are bigger atoms than steel but industrial treatments have limitation for all elements. Steel is user-friendly to put it into a fabric, economic and non-toxic for an organism. The aim of this study was to investigate the effects of fabric structural parameters, which are weave, conductive weft yarn density, fabric thickness and porosity on gamma radiation shielding effectiveness of the 2/2 twill, $3 / 1$ twill and certain derivative woven fabrics. In this regard, an experimental study has been carried out and then, the effects of the parameters have been detected firstly by graphics formed by obtained data and secondly by analysis of variance.

\section{MATERIAL AND METHODS}

\section{Material}

In this research 24 types of woven fabric samples $(42 \times 42 \mathrm{~cm})$ were produced in Weaving Workshop of in-house by $\mathrm{CCl}$ automatic sample rapier loom (Evergreen 8900, Taiwan). 100\% polyester yarns and textured stainless steel yarns, which have soft feeling and flexibility, required properties for fabrics, were used. The optical image of the textured steel yarn was taken by using Olympus BX 43 Microscopy as shown in figure 2 . The specifications of yarns are given in table 1 . Weave patterns are shown in figure 3 . While the conductive steel yarns were inserted in certain intervals to obtain different open grid structures of conductive yarn within the fabrics, which resulted in different conductive weft yarn densities, the conductive and the polyester yarns were used in 1 to 4 orders as warp yarns. The characteristics of the conductive fabrics are shown in table 2 . The open grid structures of the conductive yarns are represented with grey squares and letter of $\mathrm{T}$, whereas the polyester yarns are represented with white squares and letter of Pin figure 4. Both white and grey squares also represent intersection points between warp and weft yarns. Warp and weft settings of 24 kinds of woven fabric samples on the loom were $20 \mathrm{~cm}^{-1}$, which was calculated for the loom state. And also reference samples were woven for all kinds of weaves with only $100 \%$ polyester warp and wefts.

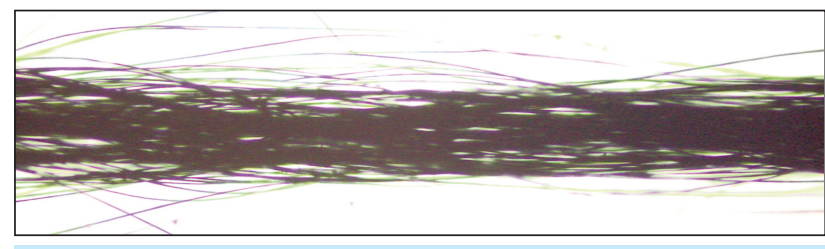

Fig. 2. Optical image of textured steel yarn

Table 1

\begin{tabular}{|l|c|c|c|}
\hline \multicolumn{1}{|c|}{ Material } & $\begin{array}{c}\text { Yarn } \\
\text { count } \\
\text { (dtex) }\end{array}$ & $\begin{array}{c}\text { Diameter } \\
\text { of wire } \\
(\mathbf{m m})\end{array}$ & $\begin{array}{c}\text { Conductor } \\
\text { resistance } \\
\left(\mathbf{\Omega} \mathbf{m m}^{2} / \mathbf{m}\right)\end{array}$ \\
\hline Polyester yarn & 600 & 0.02 & - \\
\hline Textured steel yarn & 695 & 0.037 & 0.013 \\
\hline
\end{tabular}

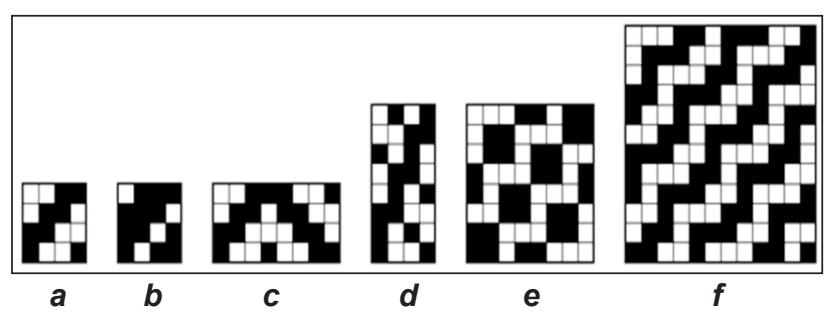

Fig. 3. Weave patterns used in experimental: $a-2 / 2$ Twill, $b-3 / 1$ Twill, $c-$ Herringbone, $d$ - Whipcord, e - Barathea, $f$ - Crêpe

Table 2

\begin{tabular}{|c|c|c|c|c|c|}
\hline $\begin{array}{l}\text { Fabric } \\
\text { code }\end{array}$ & $\begin{array}{l}\text { Weave } \\
\text { pattern }\end{array}$ & $\begin{array}{c}\text { Warp } \\
\text { density on } \\
\text { the reed } \\
\left(\mathrm{cm}^{-1}\right)\end{array}$ & $\begin{array}{c}\text { Weft } \\
\text { density on } \\
\text { the loom } \\
\left(\mathrm{cm}^{-1}\right)\end{array}$ & $\begin{array}{l}\text { Yarn } \\
\text { type* }\end{array}$ & $\begin{array}{c}\text { Fabric } \\
\text { composition } \\
\text { (warp } \times \text { weft) }\end{array}$ \\
\hline A1 & \multirow{4}{*}{ 2/2 Twill } & \multirow{4}{*}{20} & \multirow{4}{*}{20} & TP 1:1 & $1 \mathrm{~T} 4 \mathrm{P} \times 1 \mathrm{~T} 1 \mathrm{P}$ \\
\hline $\mathrm{A} 2$ & & & & TP 1:2 & $1 \mathrm{~T} 4 \mathrm{P} \times 1 \mathrm{~T} 2 \mathrm{P}$ \\
\hline A3 & & & & TP 1:4 & $1 \mathrm{~T} 4 \mathrm{P} \times 1 \mathrm{~T} 4 \mathrm{P}$ \\
\hline A4 & & & & TP 1:8 & $1 \mathrm{~T} 4 \mathrm{P} \times 1 \mathrm{~T} 8 \mathrm{P}$ \\
\hline B1 & \multirow{4}{*}{ 3/1 Twill } & \multirow{4}{*}{20} & \multirow{4}{*}{20} & TP $1: 1$ & $1 \mathrm{~T} 4 \mathrm{P} \times 1 \mathrm{~T} 1 \mathrm{P}$ \\
\hline B2 & & & & TP 1:2 & $1 \mathrm{~T} 4 \mathrm{P} \times 1 \mathrm{~T} 2 \mathrm{P}$ \\
\hline B3 & & & & TP $1: 4$ & $1 \mathrm{~T} 4 \mathrm{P} \times 1 \mathrm{~T} 4 \mathrm{P}$ \\
\hline B4 & & & & TP 1:8 & $1 \mathrm{~T} 4 \mathrm{P} \times 1 \mathrm{~T} 8 \mathrm{P}$ \\
\hline C1 & \multirow{4}{*}{ Herringbone } & \multirow{4}{*}{20} & \multirow{4}{*}{20} & TP $1: 1$ & $1 \mathrm{~T} 4 \mathrm{P} \times 1 \mathrm{~T} 1 \mathrm{P}$ \\
\hline $\mathrm{C} 2$ & & & & TP 1:2 & $1 \mathrm{~T} 4 \mathrm{P} \times 1 \mathrm{~T} 2 \mathrm{P}$ \\
\hline C3 & & & & TP $1: 4$ & $1 \mathrm{~T} 4 \mathrm{P} \times 1 \mathrm{~T} 4 \mathrm{P}$ \\
\hline C4 & & & & TP 1:8 & $1 \mathrm{~T} 4 \mathrm{P} \times 1 \mathrm{~T} 8 \mathrm{P}$ \\
\hline D1 & \multirow{4}{*}{ Whipcord } & \multirow{4}{*}{20} & \multirow{4}{*}{20} & TP 1:1 & $1 \mathrm{~T} 4 \mathrm{P} \times 1 \mathrm{~T} 1 \mathrm{P}$ \\
\hline D2 & & & & TP $1: 2$ & $1 \mathrm{~T} 4 \mathrm{P} \times 1 \mathrm{~T} 2 \mathrm{P}$ \\
\hline D3 & & & & TP 1:4 & $1 \mathrm{~T} 4 \mathrm{P} \times 1 \mathrm{~T} 4 \mathrm{P}$ \\
\hline D4 & & & & TP 1:8 & $1 \mathrm{~T} 4 \mathrm{P} \times 1 \mathrm{~T} 8 \mathrm{P}$ \\
\hline E1 & \multirow{4}{*}{ Barathea } & \multirow{4}{*}{20} & \multirow{4}{*}{20} & TP 1:1 & $1 \mathrm{~T} 4 \mathrm{P} \times 1 \mathrm{~T} 1 \mathrm{P}$ \\
\hline E2 & & & & TP $1: 2$ & $1 \mathrm{~T} 4 \mathrm{P} \times 1 \mathrm{~T} 2 \mathrm{P}$ \\
\hline E3 & & & & TP 1:4 & $1 \mathrm{~T} 4 \mathrm{P} \times 1 \mathrm{~T} 4 \mathrm{P}$ \\
\hline E4 & & & & TP 1:8 & $1 \mathrm{~T} 4 \mathrm{P} \times 1 \mathrm{~T} 8 \mathrm{P}$ \\
\hline F1 & \multirow{4}{*}{ Crêpe } & \multirow{4}{*}{20} & \multirow{4}{*}{20} & TP 1:1 & $1 \mathrm{~T} 4 \mathrm{P} \times 1 \mathrm{~T} 1 \mathrm{P}$ \\
\hline F2 & & & & TP 1:2 & $1 \mathrm{~T} 4 \mathrm{P} \times 1 \mathrm{~T} 2 \mathrm{P}$ \\
\hline F3 & & & & TP $1: 4$ & $1 \mathrm{~T} 4 \mathrm{P} \times 1 \mathrm{~T} 4 \mathrm{P}$ \\
\hline F4 & & & & TP 1:8 & $1 \mathrm{~T} 4 \mathrm{P} \times 1 \mathrm{~T} 8 \mathrm{P}$ \\
\hline
\end{tabular}

* $\mathrm{T}$ represents textured steel yarn, $\mathrm{P}$ represents polyester yarn 


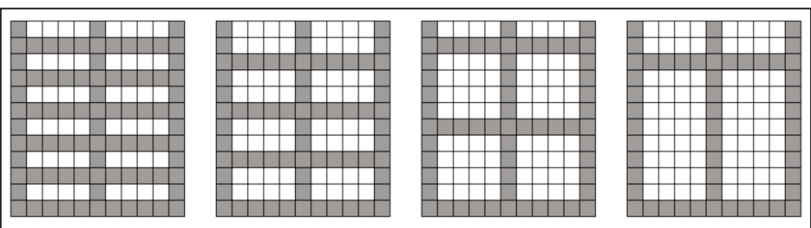

Fig. 4. Schematic diagram of open-grid structures formed in the woven fabrics (grey squares: conductive steel yarns; white squares: polyester yarns)

Fabric samples have been coded according to their weave pattern, warp and weft densities as in table 2 . The letter and number in each fabric code represent weave patterns and weft yarn arrangement respectively.

\section{Method}

The thickness of fabrics was measured with Digital Thickness Gauge Meter. Five numbers of the samples were measured.

The porosities of fabrics were calculated by [10]

$$
\varepsilon=1-\frac{\rho_{a}}{\rho_{b}}
$$

where $\rho_{a}$ is the fabric density $\left(\mathrm{g} / \mathrm{cm}^{3}\right), \rho_{b}$ is the fibre density $\left(\mathrm{g} / \mathrm{cm}^{3}\right)$ and $\varepsilon$ is the porosity. Fabric density is calculated by dividing the fabric weight per unit area, by fabric thickness.

Radiation absorption measurements of prepared samples of fabric types were performed using Geiger Muller (GM) gas filled radiation detector in the geometry as shown with figure 5. Preferring cause of GM detector is detection efficiency for total gamma radiation energy instead of spectroscopic Scintillators of semi-conductor crystals. Also dose studies are commonly based on gas filled detectors (such as ionization chambers) for all type of radiation particles in dosimetry science.

Firstly, a background (absence of non-natural radiation source) radiation was counted to correct the main counting. In step one, americium (Am-241) gamma radiation was counted several times to get mean radiation rate in determined time in geometry of figure 3 while there is no fabric sample between detector and the source. This mean value represents "I0" initial intensity of radiation beams that reach to GM detector. In step two, radiation detection-counting was done while each sample is between source and GM detector. This value represents "I" transferred part of gamma radiation by the samples. Transfer and abruption rates of the samples were calculated by fractions of $1 / / 0$. Each sample was measured five times.

Am-241 radionuclide was used as radiation source (point source geometry). Single source energy was used instead of variable energies because to use different energies the $\mathrm{x}$-ray tube is needed and properly

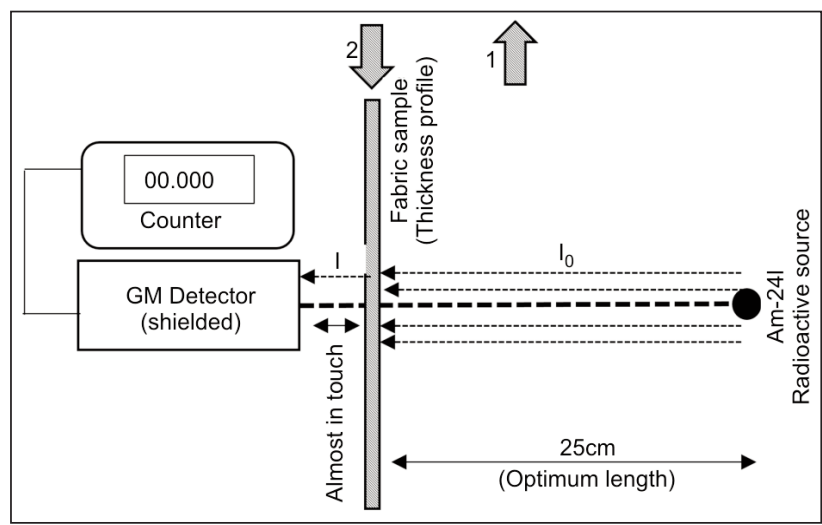

Fig. 5. Illustration of radiation (nuclear) absorption experiment. $1-I_{0}$ initial intensity was counted without a fabric sample in air media. 2 - I intensity was counted while the sample is between detector and source

radioprotection shielding during experiment. Despite this situation Am-241 has gamma energy (figure 6) in scale of $\mathrm{x}$-ray region and this region is comparable medical radiation energies.

While transferred part, $T$, was calculated from equation (2), absorbed part, $A$, was calculated from equation (3);

$$
T=\frac{I}{I_{0}} \times 100
$$

where $I_{0}$ is initial intensity, namely gamma counting without absorber, I - transferred intensity, namely gamma counting with absorber.

$$
A=100-T
$$

In this method it is not needed to calculate real intensity 10 because $\mathrm{I} / \mathrm{I0}$ rate does not change by calculating real (raw) counting rate in unit count/time.

Radiation absorption measurements were evaluated statistically by ANOVA according the General Linear Model with SPSS 15.0 software package. In order to analyze the effect of weave and conductive weft

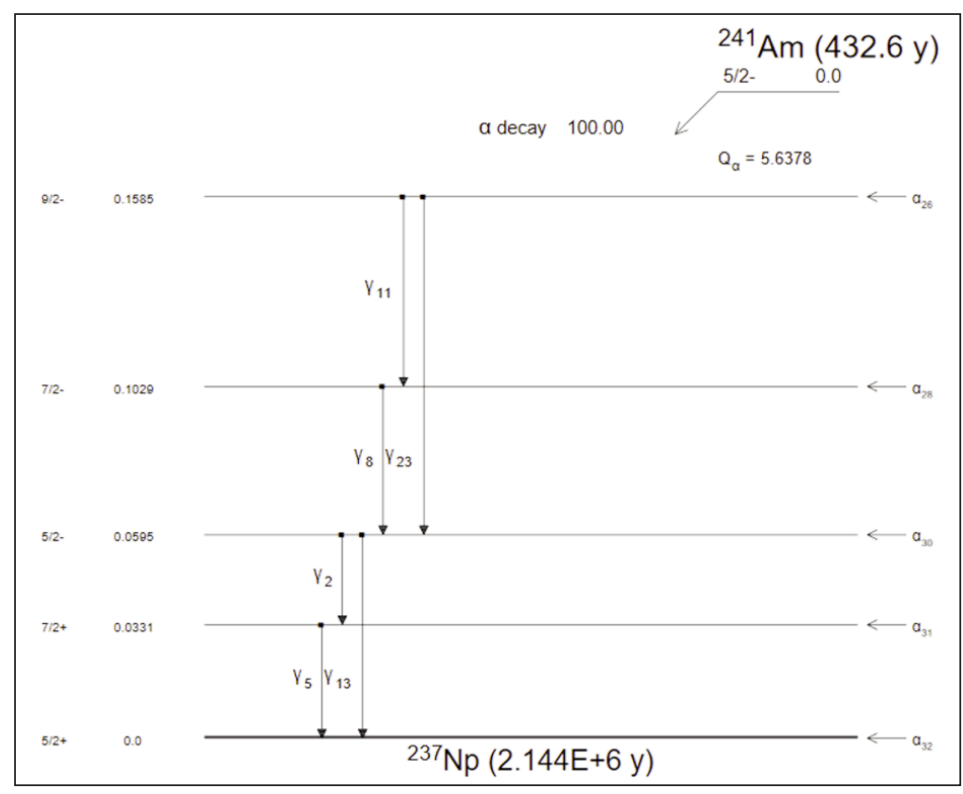

Fig. 6. Decay Scheme of Am-241 [9] 
density, multivariate analysis was made. Significance degrees $(p)$, which were obtained from ANOVA, were compared with significance level $(\alpha)$ of 0.05 . The effect, whose significance degree was lower than 0.05 , was interpreted as statistically important.

\section{RESULTS AND DISCUSSIONS}

The averages of thickness, porosities and gamma radiation measurements are given in table 3 . Initial intensity was counted as $479 \mathrm{cpm}$ (count per minute). It is seen from table 3 that if the fabric thickness increased and the porosity decreased the transferred intensity decreased.

Table 3

\begin{tabular}{|c|c|c|c|c|}
\hline $\begin{array}{c}\text { Fabric } \\
\text { code }\end{array}$ & $\begin{array}{c}\text { Thickness } \\
\text { (mm) }\end{array}$ & Porosity & $\begin{array}{c}\text { Transferred } \\
\text { intensity } \\
\text { (cpm) }\end{array}$ & $\begin{array}{c}\text { Transferred/ } \\
\text { initial } \\
\text { Percent (\%) }\end{array}$ \\
\hline A1 & 0.66 & 0.16 & 338 & 70.56 \\
\hline A2 & 0.64 & 0.17 & 341 & 71.19 \\
\hline A3 & 0.63 & 0.19 & 345 & 72.03 \\
\hline A4 & 0.62 & 0.21 & 348 & 72.65 \\
\hline B1 & 0.69 & 0.15 & 334 & 69.73 \\
\hline B2 & 0.68 & 0.16 & 337 & 70.35 \\
\hline B3 & 0.66 & 0.18 & 341 & 71.19 \\
\hline B4 & 0.65 & 0.20 & 345 & 72.03 \\
\hline C1 & 0.72 & 0.14 & 329 & 68.68 \\
\hline C2 & 0.71 & 0.15 & 333 & 69.52 \\
\hline C3 & 0.69 & 0.17 & 337 & 70.35 \\
\hline C4 & 0.68 & 0.19 & 340 & 70.98 \\
\hline D1 & 0.76 & 0.13 & 325 & 67.85 \\
\hline D2 & 0.74 & 0.14 & 328 & 68.48 \\
\hline D3 & 0.72 & 0.16 & 332 & 69.31 \\
\hline D4 & 0.71 & 0.18 & 336 & 70.15 \\
\hline E1 & 0.79 & 0.12 & 320 & 66.81 \\
\hline E2 & 0.77 & 0.13 & 323 & 67.43 \\
\hline E3 & 0.75 & 0.15 & 327 & 68.27 \\
\hline E4 & 0.74 & 0.17 & 331 & 69.10 \\
\hline F1 & 0.82 & 0.11 & 316 & 65.97 \\
\hline F2 & 0.80 & 0.12 & 319 & 66.60 \\
\hline F3 & 0.79 & 0.14 & 322 & 67.22 \\
\hline F4 & 0.78 & 0.16 & 325 & 67.85 \\
\hline
\end{tabular}

While the samples F1-F5 and E1-E5, whose thicknesses are the biggest and porosities are the lowest, have the lowest transferred intensity, the samples A1-A5 and B1-B5, whose thicknesses are the lowest and porosities are the biggest, have the highest transferred intensity. Moreover, when the density of conductive weft yarn increased, the transferred intensity is increased as expected.

The transferred and absorbed parts of radiation for each fabric are shown in figure 7 . It is observed from figure 6 that while absorbed part of radiation increased agreement with fabric thickness, transferred

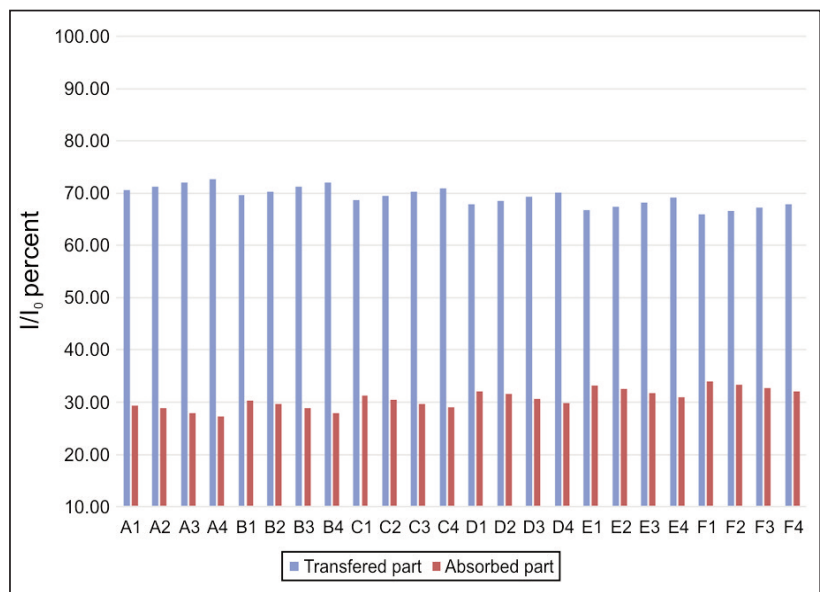

Fig. 7. The transferred and absorbed parts of radiation for fabrics

part of radiation decreased. The samples F1-F5 and E1-E5 have the lowest transferred part of radiation due to their highest fabric thicknesses, whereas; samples A1-A5 and B1-B5 have the highest transferred part of radiation due to its lowest fabric thickness. The opposite is valid for the absorbed part of radiation. When the density of textured steel yarn decreased, transferred part of radiation increased, whereas; absorbed part of radiation decreased, as expected.

The variance analysis showed that both the effects of weave and conductive weft density on gamma radiation shielding effectiveness of conductive fabrics are statistically significant, getting the $p$-values of $(0.021)$ and $(0.013)$ respectively.

\section{CONCLUSION}

The main aim of this study was to develop lead-free, fabrics for gamma radiation shielding, focusing on the attenuation properties. Therefore, experimental study was performed within the scope of this study to determine the effects of weave and fabric thickness, which are fabric structural parameters, on the gamma radiation shielding effectiveness of $2 / 2$ twill, $3 / 1$ twill and certain derivative woven fabrics.

With the highest thicknesses and lowest porosities, Barathea and Crêpe woven fabrics performed better gamma radiation shielding efficiency than other woven fabrics. Thanks to the highest fabric thicknesses and lowest porosities, the sample F1 and E1, woven with Barathea and Crêpe, show the best gamma radiation shielding effectiveness, namely absorbed part, (34.03 and $33.19 \%)$. When the conductive weft yarn density increased, gamma radiation shielding effectiveness of fabrics increased. Theoretically synthetic or organic materials are not affective on remarkable radiation absorption as it was mentioned in the introduction section but the metal components in the yarn composition of the fabric is dominant on the effective radiation shielding. Metal (steel) density in unit surface of the fabric is deterministic factor for absorption/transfer fraction. 


\section{BIBLIOGRAPHY}

[1] Başer, G. Technique and art of weaving. In: Punto Publishing, vol. 1, İzmir, 2004 (in Turkish).

[2] Hecth, E. Optics. Pearson Education, 2002.

[3] Maiin, J., Gentner, N. and Pan, Z. Sources, effects and risks of ionizing radiation. In: United Nations Scientific Committee on the Effect of Atomic Radiation (UNSCEAR), United Nations, New York, 1988.

[4] Sainis, K., Burns, P., Metter, F. and Holm, L.E. Exposure from natural sources of radiation. In: United Nations Scientific Committee on the Effect of Atomic Radiation (UNSCEAR), United Nations, New York, 1993.

[5] Yonekra, Y., Pinillos Ashton, L. and Holm, L.E. Sources, effects and risks of lonizing radiation. In: United Nations Scientific Committee on the Effect of Atomic Radiation (UNSCEAR), United Nations, New York, 2000.

[6] ICRP. 1990 Recommendations of the International Commission on Radiological Protection. In: ICRP Publication, 60 (Users' Edition), 1991.

[7] Maghrabi, H.A., Vijayan, A., Deb, P., Wang, L. Bismuth oxide-coated fabrics for X-ray shielding. In: Textile Research Journal, 2016, vol. 86, issue 6, pp. 649-658.

[8] Aral, N., Nergis, F.B., Candan, C. An alternative X-ray shielding material based on coated textiles. In: Textile Research Journal, 2015, DOI: 10.1177/0040517515590409, pp. 1-9.

[9] Qu, L., Tian, M., Zhang, X., Guo, X., Zhu, S., Han, G., Li, C. Barium sulfate/regenerated cellulose composite fiber with $X$-ray radiation resistance. In: Journal of Industrial Textiles, 2015, vol. 45, issue 3, pp. 352-367.

[10] Hseih, Y.L. Liquid transport in fabric structures. In: Textile Research Journal, 1995, vol. 65, issue 5, 299-307.

[11] Balpardo, C., Capoulat, M.E., Rodrigues, D., Arenillas, P. Standardization of Am-241by Digital Coincidence Counting, Liquid Scintillation Counting and Defined Solid Angle counting Laboratorio de Metrología de Radioisótopos. CNEA, Buenos Aires, 2009.

\section{Authors:}

\section{HAKAN ÖZDEMIR ${ }^{1}$}

BERKAY CAMGÖZ ${ }^{2}$

${ }^{1}$ Dokuz Eylül University, Faculty of Engineering, Textile Engineering Department

Tınaztepe Campus, 35397 Buca/izmir, Turkey

${ }^{2}$ Ege University, Institute of Nuclear Sciences

35100 Bornova/Izmir, Turkey

Corresponding author:

HAKAN ÖZDEMIR

e-mail: h.ozdemir@deu.edu.tr

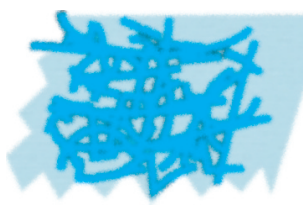

